\title{
Consideraciones Epistemológicas
}

PhD. Oscar Antonio Martínez Molina
Universidad Nacional de Educación, UNAE
oscar.martinez@unae.edu.ec
Azogues, Ecuador
https://orcid.org/0000-0003-1123-5553

\section{Editorial}

Los actores sociales que participan de la cultura no pueden estar ajenos a las variaciones o formas preestablecidas de ésta; así que en el rol de los investigadores se parte de dos premisas básicas. La primera es que, al aproximarse al objeto de la indagación, no se hace de forma desprevenida, sino que dicho acercamiento parte de un interés personal, que implica un saber previo. La segunda es que al constituirse en observadores a su vez se participa del fenómeno que se observa, contribuyendo a su construcción.

A partir de estas ideas básicas se define la postura asumida en la investigación como de carácter cualitativo, por lo que el ejercicio se dirige a la comprensión más que a la explicación; esto quiere decir que el interés es captar los significados e interpretaciones que construyen y comparten los protagonistas que intervienen en la investigación.

Si se toma como punto inicial la teoría de la interpretación socio - cultural del aprendizaje que desarrolla Vygotsky citado (Vargas, 1999a), resultado de una aproximación más histórico-interpretativa acerca de los productos culturales del hombre complementados con la cultura, la construcción de significados y el proceso de significación se construye primero por fuera; es decir, en la relación inter psicológica, cuando se recibe la influencia de la cultura reflejada en toda la producción de material (las herramientas, los desarrollos científicos y tecnológicos) o simbólica (el lenguaje, con los signos y símbolos) En segundo lugar de manera intra psicológica, cuando se transforman las funciones psicológicas superiores, es decir, se produce la 
denominada internalización, que afecta el marco interno con una aproximación desde la concepción socio constructivista. Esta última permite ver la cultura como una forma de actividad del hombre y, además, permite construir por medio de la interacción con los protagonistas, teniendo en cuenta el ser individual y la sociedad como una opción de generar conocimientos desde lo social y desde el otro.

En el desarrollo de la Humanidad siempre han estado latentes importantes preguntas: ¿cómo es que una persona construye significados tan particulares o exclusivos?, ¿qué es lo que interviene en ese proceso, para que esa persona diga "Eso me es significativo" aunque para los otros no tengan la misma significación, ¿cuál es el proceso, el mecanismo o los momentos que le permiten construir ese sentido en particular? Acaso será, como afirma Vygotsky citado por Bruner (1995), que la cultura es un conjunto de procedimientos que acceden a un estrato superior, siendo los significados los que facilitan construir un mundo posible social más complejo del que es conocido.

La construcción de significados es capaz de darle a la verdad o a lo correcto, una significación de trascendencia de acuerdo a la afirmación de Calderón (2001), al indicar que la verdad es una construcción personal y, al mismo tiempo, el resultado de las interacciones con diversos mundos posibles mentales y versiones de esos mundos, que lo enriquecen y le dan un mayor desarrollo de ampliación al mundo construido, en este caso, el de motivación a la investigación.

Como ya se mencionó, el proceso de significados de la mayoría de los artículos es en esta edición, trabajados desde Vygotsky citado por Mendoza (2010), quien desarrolla la construcción del conocimiento, que permite evidenciar la raíz social que le atribuye al conocimiento humano como resultado de la interacción de diversos mundos posibles mentales. Estos mundos posibles son primero mentales que físicos, ya que cuando se dice el 
vocablo silla se tiene ese concepto en la mente y no es que esté fuera de sí o en el mundo material; ellos pueden ser el medio social, la educación, las relaciones y otros aspectos que influyen en el desarrollo de cada ser humano.

Bajo esta cosmovisión se vería entonces la realidad como multifacética, dinámica y multidimensional. En ella no se considera al universo como absolutamente determinado, sino como generador de diversidades que dan viabilidad a la emergencia de múltiples interpretaciones, es decir, a la posibilidad de construir múltiples versiones del mundo.

Así, este paradigma da cuenta de principios subjetivos que privilegian el acoger aquellas interpretaciones que se producen en contacto con los fenómenos vivenciados por los autores. Por eso se reconoce que los investigadores muestran interés, que parte de aprendizajes previos que son los que complementan para dar respuestas a las inquietudes socio culturales.

Es evidente que con esta revolución cognitiva, cuya base es la interpretación del conocimiento y cuyo centro de interés es la construcción de significados, se trata en primer lugar de descubrir y describir formalmente los significados que los seres humanos crean a partir de sus encuentros con el mundo; luego proponer hipótesis acerca de los procesos de construcción de significados que se centran en las actividades simbólicas empleadas por los seres humanos y, así, construir y dar sentido no sólo al mundo sino también a ellos mismos.

Esta revolución rescató el concepto de mente, entendido como el hecho de hacer consciente los estados intencionales como creer, desear, pretender, captar un significado que permitió la construcción de un conocimiento entorno al concepto de significado y los procesos mediante los cuales se crean y se negocian éstos dentro de una comunidad.

Las construcciones de significados harán posible conocer el sentido de vida o de trascendencia en esos mundos creados socialmente, lo cual hace que el individuo sea parte de un mundo mental que cada uno construye y que, 
si comprende y hace suyo, puede crear otros mundos.

Para que puedan existir los mundos posibles es necesario poder construir socialmente ideas y significados públicos o compartidos. Esto es posible porque no existen, son construidos a partir de ideales, interacciones, negociaciones que se logran a través del lenguaje como un vehículo de construcción, tal como sostiene Platón en el Mito a la caverna. Estos ideales producen niveles de conciencia de los procesos de significación de algo, convirtiendo el lenguaje en vehículo que permite la repetición, reelaboración, construcción o reconstrucción de significados socialmente compartidos con un lugar dentro de la cultura del investigador. De esta forma es posible construir.

Una significación con estructuras y esquemas previos aprendidos, como son las representaciones imaginarias del quehacer del investigador para poder hacer una reelaboración de su desempeño profesional y, así, construir un significado en virtud de su participación en el entorno socio cultural, en el que se integra como uno más.

La forma de vida, adaptada culturalmente, forma parte de los significados y conceptos compartidos y depende, también, de formas de discursos compartidos que sirven para negociar las diferencias de significado e interpretación acerca de la práctica investigadora, se establece así, un mundo posible que se construye día a día en la interrelación de los protagonistas y los diversos contextos con los que entran en contacto y cuya diversidad y entramado se hace más compleja cada día por medio de la construcción diaria de los protagonistas.

Sirva como fundamento para entender un poco más este planteamiento, el Pensamiento Complejo de Morín (1999), quien, basado en la teoría de la información y de los sistemas, la cibernética y en los procesos de autoorganización biológica, construye un método que intenta estar a la altura del desafió de la complejidad. Hay tres principios sobre los cuales construye Morín lo que podría ser el paradigma de la complejidad: Principio de la 
Pertinencia del conocimiento, de la Inteligencia General y de los Problemas esenciales. Antes de entrar a desarrollar los principios, se puede analizar ¿Qué es la Complejidad?

A primera vista la complejidad es un tejido de elementos heterogéneos, inseparables y asociados; se presenta como un estadio para el abordaje de la subjetividad del individuo: sentimientos, recuerdos, vivencias expresadas de manera oral, escrita o gráfica, en el que el investigador a través de la actividad intelectual voluntaria e intencional construye su mundo fenoménico.

Desde este enfoque de la complejidad se considera importante la construcción de un modelo sistémico, es decir, un modelo complejo y representativo de la realidad, considerada como un sistema. Ello será posible si se tiene en cuenta la diversidad de los componentes, así como sus interacciones; es decir, la causalidad mutua de los procesos de una dinámica global del sistema en una participación multidimensional en la que la conducta humana es esencialmente compleja, dinámica y cambiante, y está inmersa en un contexto ecológico en el que evolucionan las personas. Además, se aborda otros órdenes de aproximación comprensiva desde la concepción de Morín, buscando trascender a otros paradigmas emergentes que intentan acceder a la dinámica de la realidad.

Dentro de las características de la complejidad hay, tres principios que pueden ayudar a pensar la misma complejidad:

1. Pertinencia del conocimiento, que permite mantener informaciones claves del mundo, que posibilite articular y organizar los conocimientos y así conocer y reconocer los problemas del mundo.

2. Inteligencia General, en este principio se plantea que mientras más poderosa sea la inteligencia general más grande es su facultad para tratar problemas especiales. El conocimiento, buscando la construcción en relación con el contexto global y complejo, debe movilizar lo que 
conoce, sabe e interpreta del mundo; dicho de otra forma, los individuos constituyen la sociedad que produce a los individuos. Desde este punto de vista se puede comparar con la construcción de significados originados por la práctica investigadora de los protagonistas que participan en ella y cómo estos protagonistas a su vez de-construyen y re-construyen esta acción integradora.

3. Los problemas esenciales, principio que hace referencia a que la parte está en el todo y el todo está en la parte, como lo sostiene la Gestalt.

La otra perspectiva desde la cual se parte para dar cuenta de este fenómeno es el socio-constructivismo. El mismo se fundamenta en la siguiente premisa: los seres humanos crean y construyen dinámicamente su realidad personal y de esta forma se orientan activamente hacia una comprensión significativa del mundo en que viven, esta construcción se da en y a partir del lenguaje conllevando la formación de significados que dan sentido a la experiencia y marco interno del individuo dentro del mundo, al mundo y a la relación de estos tres.

De acuerdo con esto, lo social para los seres humanos se construye en el lenguaje, en el que se crean a sí mismos; es decir que, el lenguaje es generativo, crea realidades y posibilita la acción. Conectar el lenguaje con la acción posibilita una comprensión nueva de la acción humana, permitiendo la reconstrucción del entorno social en que se enmarca la investigación.

De esta manera, la estructura y el uso del lenguaje está relacionado de forma intrincada con la acción. Dentro de las características esenciales del acto, la intencionalidad cumple un papel fundamental, ya que rompe con la simple posición explicativa del mundo estimulo-respuesta, otorgándole al individuo una amplia gama de actitudes relacionadas con su marco socio cultural. Se posibilita de esta manera, que el hombre pueda tener la opción de elegir e, igualmente se le asigne un papel transformador e histórico al devenir 
cotidiano, ya que, al ser protagonista activo en su entorno y coparticipe de la construcción de la cultura, participa dinámicamente en la elaboración del tejido comunicacional.

Vygotsky citado por (Vargas, 1999b), a este respecto, propone que la construcción, resultado de una experiencia de aprendizaje, no se transmite de una persona a otra de manera mecánica como si fuera un objeto, sino mediante operaciones mentales que se suceden durante la interacción del sujeto con el mundo material y social.

Es así como, desde esta perspectiva no se toma un papel de espectadores, pues siempre estamos en interacción, configurando contextos de relación que fluyen continuamente, de modo que no se cristalizan, solo se transforman. Su estabilidad está dada por el cambio constante, por ello el rol de investigadores es activo, se observa y así se participa en la construcción del objeto de estudio. A su vez, desde esta perspectiva la investigación se considera como un hecho motivado desde el interior por intereses individuales y grupales.

De acuerdo con lo anterior, el lenguaje tiene una particular relevancia, pues es asumido (desde el Construccionismo Social) no como un conjunto de signos que representan al mundo y la realidad, sino como la forma desde la que de acuerdo con nuestra condición humana construimos la realidad, de modo que en el lenguaje los individuos se constituyen como seres sociales, creando y recreando la concepción y significado en un proceso en continua reconstrucción.

Desarrollando una epistemología del observador participante, centrada en la pregunta ¿cómo se conoce? y no ¿qué se conoce?, se sostiene lo que se conoce como resultado del observador y no de lo observado. Es el lenguaje el que genera la noción de objetividad, desde la que se puede acceder al conocimiento de la cultura democrática o de la participación de todos los elementos que rodean a los protagonistas. Ello exige que conscientemente se 
desarrolle un conocimiento, todo lo consciente que pueda ser, de los valores que llevan a adoptar esta perspectiva, exigiendo que se haga responsable de cómo se conoce y por qué. Pero no se pretende que haya una sola forma de construir el significado o una sola forma correcta de hacerlo. Hay que tener en cuenta que se sustenta en valores, que son los que mejor se adecuan para hacer frente a los cambios y fracturas que se han convertido en un rasgo tan característico de la vida moderna.

Para acceder al proceso de construcción de significados estos artículos toman en consideración la perspectiva socio constructivista. A través de esta se permite acceder a la subjetividad del hombre, a los actos de significado, comprendiéndolos e interpretándolos en su escenario cultural y al individuo como un ser en interacción continua con otros quienes construyen ese ambiente donde se comporta de una determinada forma y en el que participa de la construcción de significaciones, ya que trata de la parte social y sus interacciones.

El investigador hace suyas las propiedades del problema estudiado a partir de la forma en que se orientan, interpretan o representan los protagonistas en su mundo donde son coprotagonistas de sus relatos y narrativas, buscando conceptualizar sobre la realidad con base en el comportamiento y los conocimientos de los actores principales.

El proceso de investigación cualitativa explora de manera sistemática los conocimientos y valores que comparten los protagonistas en un determinado contexto espacial y temporal. De este modo se puede develar que los significados forman parte de ese mundo, de ese compartir acerca del quehacer del ser humano especificando la construcción de significados acerca de su práctica investigadora, como parte de ese ver a través de los ojos de los actores la realidad. Igualmente se pretende indagar como el investigador interviene en los procesos de construcción siendo participe de esa dinámica.

En el marco de las observaciones anteriores, se puede señalar que el 
individuo es consciente del proceso de investigación cualitativa, el cual requiere un co-construir y ser parte de las diversas interrelaciones que se presentan en la construcción del significado sobre la construcción del conocimiento.

De esta forma se puede comprender que las experiencias y actos de los protagonistas son los que están moldeados por sus estados intencionales y que estos estados sólo pueden plasmarse mediante la participación en los sistemas simbólicos de la cultura donde están inmersos. Además, la investigación cualitativa hace referencia a las distinciones sociales, políticas, humanas y económicas que presentan los protagonistas en la vida cotidiana, siendo conscientes de estas, para enriquecer la deconstrucción y reconstrucción por medio de la significación de las vivencias que se realizan.

Palabras clave: epistemología; investigación; editorial. 


\section{Epistemological Considerations}

\section{Editorial}

The social actors that participate in the culture can not be alien to the variations or pre-established forms of it; so in the role of researchers, we start from two basic premises. The first is that, when approaching the object of the inquiry, it is not done in an unprepared way, but that this approach is based on a personal interest, which implies prior knowledge. The second is that by becoming observers in turn participates in the phenomenon that is observed, contributing to its construction.

Based on these basic ideas, the position assumed in the research is defined as qualitative, so that the exercise is aimed at understanding rather than explaining; This means that the interest is to grasp the meanings and interpretations that are constructed and shared by the protagonists involved in the research.

If we take as a starting point the theory of socio - cultural interpretation of learning that Vygotsky develops cited (Vargas, 1999a), result of a more historical - interpretative approach about the cultural products of man complemented with culture, the construction of meanings and the process of signification is constructed from the outside first; that is, in the inter psychological relation, when the influence of the culture reflected in all the production of material (tools, scientific and technological developments) or symbolic (language, with signs and symbols) is received. intra psychological way, when the higher psychological functions are transformed, that is, the socalled internalization occurs, which affects the internal framework with an approach from the socio-constructivist conception. The latter allows us to see culture as a form of human activity and, in addition, allows building through interaction with the protagonists, taking into account the individual being and society as an option to generate knowledge from the social and from the other. 
In the development of Humanity, important questions have always been latent: how is it that a person constructs such particular or exclusive meanings? What is involved in this process, for that person to say "That is significant to me", although for the others do not have the same meaning, what is the process, the mechanism or the moments that allow it to construct that particular sense? It may be, as Vygotsky says quoted by Bruner (1995), that culture is a set of procedures that access a higher stratum, with meanings that facilitate the construction of a possible social world more complex than is known.

The construction of meanings is capable of giving the truth or right, a significance of transcendence according to the statement of Calderón (2001), by stating that truth is a personal construction and, at the same time, the result of interactions with various possible mental worlds and versions of those worlds, which enrich it and give it a greater development of expansion to the built world, in this case, the motivation to research.

As already mentioned, the meaning process of most of the articles is in this edition, worked from Vygotsky cited by Mendoza (2010), who develops the construction of knowledge, which allows demonstrating the social root that attributes to human knowledge as result of the interaction of various possible mental worlds. These possible worlds are mental rather than physical, since when the word chair is used one has that concept in the mind and it is not that it is outside of itself or in the material world; they can be the social environment, education, relationships and other aspects that influence the development of each human being.

Under this worldview we would then see reality as multifaceted, dynamic and multidimensional. In it, the universe is not considered as absolutely determined, but as a generator of diversities that give viability to the emergence of multiple interpretations, that is, to the possibility of constructing multiple versions of the world.

Thus, this paradigm accounts for subjective principles that privilege the 
acceptance of those interpretations that occur in contact with the phenomena experienced by the authors. That is why it is recognized that researchers show interest, that part of previous learning that complements to give answers to socio-cultural concerns.

It is evident that with this cognitive revolution, whose basis is the interpretation of knowledge and whose center of interest is the construction of meanings, it is first of all to discover and formally describe the meanings that human beings create from their encounters with the world; then propose hypotheses about the processes of construction of meanings that focus on the symbolic activities used by human beings and, thus, build and give meaning not only to the world but also to themselves.

This revolution rescued the concept of mind, understood as making conscious intentional states such as believing, wanting, pretending, grasping a meaning that allowed the construction of knowledge around the concept of meaning and the processes by which they are created and they negotiate these within a community.

The constructions of meanings will make it possible to know the sense of life or transcendence in those socially created worlds, which makes the individual part of a mental world that each one constructs and that, if he understands and makes his own, he can create other worlds.

For possible worlds to exist, it is necessary to be able to socially construct public or shared ideas and meanings. This is possible because they do not exist, they are constructed from ideals, interactions, negotiations that are achieved through language as a vehicle of construction, as Plato maintains in the Mito to the cavern. These ideals produce levels of awareness of the processes of meaning of something, converting language into a vehicle that allows the repetition, re-elaboration, construction or reconstruction of socially shared meanings with a place within the culture of the researcher. In this way it is possible to build. 
A meaning with structures and previous learned schemes, such as the imaginary representations of the researcher's task to be able to rework their professional performance and, thus, build a meaning by virtue of their participation in the socio-cultural environment, in which they integrate as one more.

The way of life, culturally adapted, is part of the shared meanings and concepts and also depends on forms of shared discourses that serve to negotiate the differences of meaning and interpretation about the research practice, thus establishing a possible world that it is built day by day in the interrelation of the protagonists and the diverse contexts with which they come into contact and whose diversity and network becomes more complex each day by means of the daily construction of the protagonists.

It serves as a basis to understand a little more this approach, the Complex Thought of Morin (1999), who, based on the theory of information and systems, cybernetics and the processes of biological self-organization, builds a method that tries to be up to the challenge of complexity. There are three principles on which Morín constructs what could be the paradigm of complexity: Principle of the Relevance of Knowledge, of General Intelligence and of Essential Problems. Before entering to develop the principles, you can analyze What is Complexity?

At first sight, complexity is a fabric of heterogeneous, inseparable and associated elements; It is presented as a stage for addressing the subjectivity of the individual: feelings, memories, experiences expressed orally, written or graphically, in which the researcher, through voluntary and intentional intellectual activity, constructs his phenomenal world.

From this approach to complexity, the construction of a systemic model is considered important, that is, a complex and representative model of reality, considered as a system. This will be possible if the diversity of the components is taken into account, as well as their interactions; that is, the mutual causality 
of the processes of a global dynamics of the system in a multidimensional participation in which human behavior is essentially complex, dynamic and changing, and is immersed in an ecological context in which people evolve. In addition, other orders of comprehensive approach from the conception of Morin are addressed, seeking to transcend other emerging paradigms that try to access the dynamics of reality.

Within the characteristics of complexity there are three principles that can help to think the same complexity:

1. Pertinence of knowledge, which allows keeping key information of the world, which makes it possible to articulate and organize knowledge and thus know and recognize the problems of the world.

2. General Intelligence, in this principle it is stated that the more powerful the general intelligence is, the greater its ability to deal with special problems. Knowledge, seeking construction in relation to the global and complex context, must mobilize what it knows, knows and interprets of the world; In other words, individuals constitute the society that produces individuals. From this point of view it can be compared with the construction of meanings originated by the investigative practice of the protagonists that participate in it and how these protagonists in turn deconstruct and re-construct this integrating action.

3. The essential problems, a principle that makes reference to the fact that the part is in the whole and the whole is in the part, as the Gestalt maintains.

The other perspective from which one starts to account for this phenomenon is socio-constructivism. It is based on the following premise: human beings dynamically create and build their personal reality and in this way are actively oriented towards a meaningful understanding of the world in 
which they live, this construction occurs in and from the language entailing the formation of meanings that give meaning to the experience and inner frame of the individual within the world, to the world and to the relationship of these three.

According to this, the social for human beings is constructed in language, in which they create themselves; that is to say, language is generative, creates realities and enables action. Connecting language with action enables a new understanding of human action, allowing the reconstruction of the social environment in which research is framed.

In this way, the structure and use of language is intricately related to the action. Within the essential characteristics of the act, intentionality plays a fundamental role, since it breaks with the simple explanatory position of the stimulus-response world, giving the individual a wide range of attitudes related to their socio-cultural framework. It is possible in this way, that man can have the option of choosing and, equally, be assigned a transforming and historical role to the daily becoming, since, being an active protagonist in his environment and co-participant in the construction of culture, he participates dynamically in the elaboration of the communicational fabric.

Vygotsky cited by (Vargas, 1999b), in this regard, proposes that construction, the result of a learning experience, is not transmitted from one person to another mechanically as if it were an object, but by mental operations that occur during the interaction of the subject with the material and social world.

This is how, from this perspective, a role of spectators is not taken, because we are always in interaction, configuring contexts of relationship that flow continuously, so that they do not crystallize, they only transform. Its stability is given by the constant change, for that reason the role of researchers is active, it is observed and thus it participates in the construction of the object of study. In turn, from this perspective, research is considered as a fact 
motivated from within by individual and group interests.

According to the above, language has a particular relevance, since it is assumed (from Social Constructionism) not as a set of signs that represent the world and reality, but as the form from which, according to our human condition, we construct the reality, so that in the language the individuals are constituted as social beings, creating and recreating the conception and meaning in a process in continuous reconstruction.

Developing an epistemology of the participant observer, centered on the question, how is it known? and not what is known?, it is sustained what is known as the result of the observer and not the observed. It is the language that generates the notion of objectivity, from which one can access the knowledge of the democratic culture or the participation of all the elements that surround the protagonists. This requires consciously developing a knowledge, as conscious as it may be, of the values that lead to adopting this perspective, demanding that it be held responsible for how it is known and why. But it is not intended that there be a single way of constructing the meaning or a single correct way of doing it. We must bear in mind that it is based on values, which are the best suited to cope with the changes and fractures that have become such a characteristic feature of modern life.

To access the process of meaning construction, these articles take into consideration the socio-constructivist perspective. Through this is allowed to access the subjectivity of man, the acts of meaning, understanding and interpreting them in their cultural setting and the individual as a being in continuous interaction with others who build that environment where it behaves in a certain way and in the one that participates in the construction of meanings, since it deals with the social part and its interactions.

The researcher endorses the properties of the problem studied from the way they are oriented, interpreted or represented by the protagonists in their world where they are co-protagonists of their stories and narratives, seeking to 
conceptualize reality based on the behavior and knowledge of principal actors.

The qualitative research process systematically explores the knowledge and values shared by the protagonists in a specific spatial and temporal context. In this way it can be revealed that the meanings are part of that world, of that sharing about the task of the human being specifying the construction of meanings about their research practice, as part of seeing through the eyes of the actors the reality. It is also intended to investigate how the researcher intervenes in the construction processes by participating in this dynamic.

Within the framework of the previous observations, it can be pointed out that the individual is aware of the qualitative research process, which requires a co-construct and be part of the various interrelationships that arise in the construction of meaning about the construction of knowledge.

In this way it can be understood that the experiences and acts of the protagonists are those shaped by their intentional states and that these states can only be expressed through participation in the symbolic systems of the culture where they are immersed. In addition, qualitative research refers to the social, political, human and economic distinctions that the protagonists present in everyday life, being aware of these, to enrich the deconstruction and reconstruction through the meaning of the experiences that are made.

Keywords: epistemology; research; publishers. 


\section{Referencias}

Bruner, J. (1995). Actos de significado, más allá de la revolución cognitiva, ISBN: 9788420648125. Madrid, España: Alianza Editorial, 168 págs.

Calderón, R. (2001). Constructivismo y Aprendizajes Significativos. monografias.com. [Documento en línea], 2 págs. Recuperado de: http://www.monografias.com/trabajos7/aprend/aprend.shtml

Mendoza, J. (2010). Vygotsky y la construcción del conocimiento. Boletín Electrónico de Investigación de la Asociación Oaxaqueña de Psicología A.C., 6(1), 159-164. Recuperado de:

http://www.imbiomed.com.mx/1/1/articulos.php?method=showDetail\&id articulo=61625\&id seccion $=3769$ \&id ejemplar $=6202 \& i d$ revista $=166$

Morín, E. (1999). Los siete saberes necesarios para la educación del futuro. Código del documento: EPD.99/WS/3, EPD.99/WS/4. París, Francia: Organización de las Naciones Unidas para la Educación, la Ciencia y la Cultura - Santillana/UNESCO, 67 págs. Recuperado de: https://unesdoc.unesco.org/ark:/48223/pf0000117740 spa

Vargas, M. (1999a,b). La construcción mental bajo un enfoque social. Caracas, Venezuela: División de publicaciones UNA. 


\section{PhD. Oscar Antonio Martínez Molina \\ e-mail: oscar.martinez@unae.edu.ec}

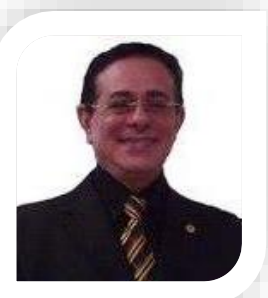

Nacido es San Cristóbal, estado Táchira, Venezuela. Residenciado en Cuenca, Ecuador. Licenciado en Educación Mención Orientación Educativa y Profesional (Universidad de Los Andes, Extensión Táchira). Magíster en Ciencias de la Educación Superior, Mención Andragogía (UNELLEZ). Doctor en Educación Mención Suma Cum Laude (Universidad de Málaga, España), Postdoctor en Estudios Libres de la Universidad Fermín Toro. Diplomado en Educación Abierta y a distancia (Universidad Fermín Toro). Maestría Experto avanzado en E-learning en la Fundación para la actualización tecnológica de Latinoamérica (FATLA). Maestría Experto en Tecnología Educativa nivel avanzado en la Fundación para la actualización tecnológica de Latinoamérica (FATLA). Profesor Jubilado de la Universidad Nacional Abierta. Categoría Académica de Titular. Director de tesis doctorales y de maestría. Responsable de la línea en enseñanza-aprendizaje de investigación del COBAIND. Representante del convenio Editorial Académica Española-COBAIND. Coordinador de la línea de investigación en Educación en la UNEFA Barinas. Presidente/Fundador del Consejo Barinés de Investigación y Desarrollo. Profesor investigador del Programa de Estímulo a la Innovación e Investigación en categoría "A-2". Docente investigación de la Universidad Nacional de Ecuador. 